\title{
THE HR COMPETENCIES ON ORGANIZATIONAL PERFORMANCE IN IT / ITES COMPANIES IN CHENNAI
}

\author{
LAVANYA IYENGAR
}

Research Scholar, Annamalai University, Chennai, Tamil Nadu, India

\begin{abstract}
This research paper highlights the context within which IT/ITES Industry has grown in India and the extent of human resource performance and systems practiced in the sector. Using a mixed method approach involving both indepth discussion with senior HR executives and self-completing questionnaires, the data have been collected from selected IT/ITES companies of Chennai city. The outcomes highlight the way specific HR competencies in organizational performance such as recruitment, performance appraisal, training and development, and compensations are implemented. The study suggests the existence of formal, structured, and rationalized HR systems in IT/ITES organizations. A number of insights related to HR policies and performance are shared by the HR senior executives interviewed shedding more light on the functioning of the IT/ITES companies and their challenges. The analysis provides original and useful information to both academicians and practitioners and opens avenues for further research in the area of HR systems and performance in the Indian IT/ITES industry.

KEYWORDS: HR Competencies, Organizational Performance \& IT/ITES Industry
\end{abstract}

Received: Jan 15, 2019; Accepted: Feb 05, 2019; Published: Feb 15, 2019; Paper Id.: IJHRMRAPR20197

\section{INTRODUCTION}

Human influence in business has been constantly rising since the Industrial Revolution, even after machine and automation has increased to a great extent. There is a shift in the role of humans in business, earlier humans were more into physical part, now it is increasing on the intellect part. Technology will always help in making things simple and easy but to remain relevant and stay competitive, effective human involvement is indispensable for today's businesses. Among all sectors in India IT-ITES sector has been one of the sector remaining in the lime light in last 30 years. With abundant intellectual capital in India, the sector has better possibilities of growth. The sector has increased its contribution to India's GDP from 1.2\% in FY1998 to $7.5 \%$ in FY2017. As this sector recruits intellectual capital, effectively motivating this intellectual capital - intellectuals is a very big challenge. Human Resource Management performance has also increased in India and a lot of research work is also carried out on effective implementations of HRM principles for growth of any business enterprise. This paper is also another such effort in the same direction, looking for HRM performance prevalent in IT-ITES Industry.

\section{Compensation}

Compensation is a system of supplying economic cost of personnel for the work they have done. Compensation can be used to rent professional employees, praise the performance, inspire agency loyalty by using reduce turnover. Compensation may additionally encompass Basic Pay, Overtime, Bonuses, 
Travel/Accommodation Allowance, Stock Options, Medical Allowance, Commissions, and Profit Sharing. A latest study conducted by Hay factors out that $20 \%$ personnel plan to exchange their modern-day positions in at least 5 years. Employee retention, turnover has ended up an extra outstanding element of organizational lifestyles. The implementation of retention reimbursement techniques has seen giant growth over the ultimate several years. A study performed by way of Frye (2004) display positive dating between repayment and company overall performance. Frye (2004) said that repayment strategies play an essential function in recruiting and retaining professional employees. Most of the firms used Performance-based totally compensation to reward employees (Collins and Clark, 2003). Performance-based totally reimbursement positively impacts worker's performance (Brown et al., 2003). A research study via Huselid (1995) confirmed a significant courting between compensations and worker overall performance. An effective HR strategy is to integrate overall performance and reimbursement machine that enhance worker's will to work efficaciously and correctly (Wright, 2003). Teseema and Soeters (2006) imply an enormous correlation between compensation and employee's performance. It is critical that agency view reimbursement performance in a favourable light as reimbursement performance heavily impact worker recruitment, turnover and productivity.

\section{ABOUT IT-ITES INDUSTRY}

\section{Information Technology in India}

The Information Technology (IT) industry is one of the fastest growing sectors in India. India has successfully established itself as a competitive and a prominent destination for outsourcing IT \& IT enabled services over the last decade. Government of India and the State Governments have put up efforts like, liberalization of external trade, elimination of duties on imports of information technology products, relaxation of controls on both inward and outward investments and foreign exchange, setting up of Export Oriented Units (EOU), Software Technology Parks (STP), and Special Economic Zones (SEZ), which helped IT industry to gain dominant position in world's IT scenario. Over the past decade, the IT / ITES industry in India has been a story of unparalleled growth. The compounded annual growth rate (CAGR) of the industry has been over $25 \%$ in the last 5 years. Most of the Indian firms, across all other sectors, largely depend on the IT \& ITES service providers to make their business processes efficient and streamlined. The Indian manufacturing sector has the highest IT spending followed by automotive, chemicals and consumer products industries.

\section{ITES}

ITES refers to Information technology enabled services. BPO or Business process outsourcing is the arm of ITES, which facilitates delivery of services through the use of information technology. ITES services are diverse in nature. It's easier to understand by segregating it as customer interactive services and back office operations for remote customers. India based service providers can deliver services in diverse areas such as finance, HR, administration, healthcare, telecommunication and manufacturing. Services ranging from customer care, call centers and claims processing to medical transcription, HR hiring, biotech research, Web sales/marketing and back-office operations such as accounting, data processing, and data mining harness the power of IT.

However, it necessitates the transfer of ownership and management of the process from the customer (offshore) to India-based service provider in order to deliver service to remote areas through telecom and Internet medium. Sensing its advantages, host of fortune 500 and fortune 1000 businesses of all sizes have set up their own BPO units or have outsourced to Indian firms to reap the advantages of this all-encompassing business revolution. 


\section{STATEMENT OF THE PROBLEM}

- This takes a study opens beautiful vistas over on management graduates HR competencies on organizational performance in IT / ITES companies of various important goals. The impact of differences in the HR competencies among the mangers in IT/ITES companies in Chennai conduct is illustrated through applications to the studies literature on method loss and pastime are searching for to diagnosed employability abilities in IT/ITES companies particularly high order thinking, interpersonal, private, hassle fixing and technical abilities. The researcher found that point control, adaptability, conversation, facts and records, revolutionary thinking, control, crew work, choice making, hassle solving, planning and organizing, self-management, reading, This study covers the of manipulate graduates employability talents of facts technology zone.

\section{SIGNIFICANCE OF THE STUDY}

In this have a look at to have a look at the various factors affects in control graduates employability abilities of records era area. This look at is classed excellent employability competencies of facts technology quarter, there through distinct of the time manage, adaptability, communique, statistics and knowledge, revolutionary thinking, leadership, team paintings, choice making, problem-solving, planning and organizing, self-control, studying there taken into consideration paintings will endow with beneficial insights too on top of things graduates employability capabilities of the facts generation region.

The study was conducted with the following objectives:

- To study the HR competency level in IT/ ITES companies in Chennai

- To find out if there are any differences in the HR competencies among the managers in IT/ITES companies in Chennai

- To study the relationship between HR competencies and organizational performance

The above study was based on the following hypotheses:

$\mathbf{H}_{\mathbf{0}}$ There is no relationship between HR competencies and organizational performance

$\mathbf{H}_{\mathbf{0}}$ There is no difference in the influence of each HR competency with respect to the Organizational performance.

\section{Research Gap}

The determinants of management graduates' employability abilities in the statistics era area which plays an important position in the power improvement of Indian economy in phrases of employment and has recorded an excessive charge of growth due to the fact that independence inspires of first-rate competition from the important sector and so encouraging guide. Moreover, the fourth census (2017-2018), Information technology the maximum of industries registered is of producing, assembling, processing, repairing and maintenance in nature. The survey of a statistics era quarter additionally shows to hat $84.08 \%$ recorded was a proprietary organization, which means they may perform the idea of employability abilities openly or hidden of their sectors. Hence Information Technology zone has been recounted as a developing and a maximum crucial one for the cities, districts and states workforce improvement of the USA. The predominant aim of the take a look at is consequently to find out control graduate's employability competencies in records technology quarter. 


\section{LOCATION OF THE STUDY}

The Research followed a simple random method. In India we've got massive numbers of IT companies; They become no longer feasible to gather statistics from each one, so researcher found in Chennai town most effective. The respondents are citizens of Chennai at the age of 20 to 60 years. Including the specific strata of employees, the point of interest of the examine consequently is to discover management graduate's employability competencies in statistics generation quarter, protecting time control, adaptability, verbal exchange, information and expertise, innovative questioning, leadership, group work, decision making, problem solving, planning and organizing, self-management and learning.

\section{Field Work and Sources of Data}

The researcher used a structured interview agenda for a reason for private interviews. Interviews are carried out in demographic traits earlier than the meeting, proper expertise is traditional. The information gathered is recorded by the researcher inside the interview agenda. The schedules thus filled up are systematically checked to make certain accuracy, reliability, and totality. On a mean, every interview took about an hour. The facts for this reason amassed had been classified and posted in the grasp table for besides processing. The era of items for employability abilities, primarily, the observe was based on the employability skills in facts era region in Chennai, and issue inflecting in employability abilities. The records accrued by way of the researcher primary as well as secondary resources have been relevant for gathering important statistics pertaining concerning to the research trouble in hand had been used in the examine. Fundamental facts based has been collected from the employability abilities through self-personalized and properly structured questionnaire. Secondary statistics have been generated from journals, books, annual reports, mag, newspaper and Internet source has also helped to gather number one facts.

\section{RESEARCH METHODOLOGY}

\section{Research Design}

The HR competencies on Organizational performance in IT/ ITES companies in Chennai

\section{Data Collection Instruments and Sampling Techniques}

A questionnaire designed for a 5-point Likert scales range from strongly disagree to strongly agree, was used to collect data from the employees working in different departments of textile sector. A questionnaire was divided in two parts: first part was comprised of data regarding HRM performance and the employee's performance and the second part with demographic information of respondents. For this research study, Random sampling technique was used for the collection of data. A questionnaire was distributed among 68 targeted respondents to get the data required for conducting the analysis.

\section{Data Analysis}

A Pearson correlation and regression was conducted to determine the association between HR performance and employee's performance. 


\section{LIMITATION OF THE STUDY}

This takes a look at is protected utilizing via questionnaire survey approach. This survey method categorized into classes one is done by the corporation and left of them college students. The researcher becomes included more straightforward IT/ITES sector handiest. This takes a look at turned into additionally restrained to Chennai, due to the fact it's far one of the first metropolitan towns in India wherein the general public have been running depends upon capabilities and expertise. The findings, pointers, and the conclusion can be applicable handier to the IT quarter employees and its impacts on delight and not for other a part of cities. In this have a look at labelled to the variance of the worker's potential and attitude. They facilitate to the inherent ability of the worker in IT zone. They are the element of the sizable affected in this observe.

\section{METHODOLOGY OF RESEARCH}

\section{Research Design}

The Research study HR competencies on Organizational performance in IT/ ITES companies in Chennai

\section{Data Collection Instruments and Sampling Techniques}

A questionnaire was designed for a 5-point Likert scales range from strongly disagree to strongly agree, was used to collect data from the employees working in different departments of textile sector. The Questionnaire was divided in two parts: first part was comprised of data regarding HRM performance and the employee's performance and the second part with demographic information of respondents. For this research study, Random sampling technique was used for the collection of data. A questionnaire was distributed among 68 targeted respondents to get the data required for conducting the analysis.

\section{Data Analysis}

A Pearson correlation and regression was conducted to determine the association between HR performance and employee's performance.

\section{RESULTS \& DISCUSSIONS}

The results of the study were given below

Table 1: Personal Characteristics of the Respondents

\begin{tabular}{|l|l|c|c|}
\hline \multicolumn{2}{|c|}{ Personal Characteristics } & Frequency & Percent \\
\hline \multirow{4}{*}{ Age } & Less than 25 years & 108 & 54 \\
\cline { 2 - 4 } & $26-35$ years & 92 & 46 \\
\cline { 2 - 4 } & \multicolumn{1}{|c|}{ Total } & $\mathbf{2 0 0}$ & $\mathbf{1 0 0}$ \\
\hline \multirow{4}{*}{ Gender } & Male & 120 & 60 \\
\cline { 2 - 4 } & Female & 80 & 40 \\
\cline { 2 - 4 } & Total & $\mathbf{2 0 0}$ & $\mathbf{1 0 0}$ \\
\hline \multirow{4}{*}{ Designation } & Customer Support Specialist & 106 & 53 \\
\cline { 2 - 4 } & Network Engineer & 48 & 24 \\
\cline { 2 - 4 } & Software Engineer & 46 & 23 \\
\cline { 2 - 4 } & Total & $\mathbf{2 0 0}$ & $\mathbf{1 0 0}$ \\
\hline \multirow{3}{*}{ Qualification } & Under Graduation & 148 & 74 \\
\cline { 2 - 4 } & Post Graduation & $\mathbf{2 0 0}$ & $\mathbf{1 0 0}$ \\
\cline { 2 - 4 } & Total & 156 & 78 \\
\hline Work Experience & Less than 5 years & & \\
\hline
\end{tabular}




\begin{tabular}{|c|c|c|c|}
\hline & Above 5 years & 44 & 22 \\
\cline { 2 - 4 } & Total & $\mathbf{2 0 0}$ & $\mathbf{1 0 0}$ \\
\hline
\end{tabular}

From the above table, it is inferred that out of 200 respondents, $54 \%$ of the employees were under 25 years and $46 \%$ were being above 26 years. With respect to gender, $60 \%$ were male and $40 \%$ were female. With regards to the designation of the respondents, $53 \%$ of them are working as a customer support specialist, followed by $24 \%$ were network engineers and $23 \%$ were software engineers. Pertaining to the qualification, most of the respondents were graduates and $26 \%$ have held a master degree. Considering education, $78 \%$ of the respondents have less than 5 years of experience in the industry, so they are considered as entry level engineers and $22 \%$ having more than 5 years of experience.

\section{Determinants of Organizational Performance}

The determinants of the Organizational performance in IT employees were identified using factor analysis. Factor analysis is a statistical procedure used to identify a small number of factors that can be used to represent relationships among a set of interrelated variables.

Table 2: KMO and Bartlett's Test

\begin{tabular}{|l|l|c|}
\hline \multicolumn{2}{|l|}{ Kaiser-Meyer-Olkin Measure of Sampling Adequacy. } & 0.893 \\
\hline Bartlett's Test of Sphericity & Approx. Chi-Square & 5236 \\
\hline & Df & 120 \\
\hline & Sig. & 0 \\
\hline
\end{tabular}

The Kaiser-Meyer-Olkin Measure of Sampling Adequacy is a statistics that indicates the proportion of variance in variable that might be caused by underlying factors. High values (close to 1.0) generally indicate that a factor analysis may be useful with the data. If the value is less than 0.50 , the result of the factor analysis probably won't be very useful. In this study, the value of Kaiser-Meyer-Olkin Measure of Sampling Adequacy is 0.893 which indicates meritorious i.e. high level of adequacy for measurement of the Organizational performance in IT employees. Furthermore, based on these loadings 16 items reduced into 5 significant factors that influence employability skill of the employees. The positive values show positive loadings on the factors extracted and the negative values show inverse relationships. The factors can be explained by arranging employee variables from the questionnaire, into 5 groups based on highest Component Matrix loadings per statement, as below.

Table 3: Results of Exploratory Factor Analysis

\begin{tabular}{|l|c|c|c|c|c|}
\hline & $\begin{array}{c}\text { Interpersonal } \\
\text { Skill }\end{array}$ & $\begin{array}{c}\text { Functional } \\
\text { Skill }\end{array}$ & $\begin{array}{c}\text { Technical } \\
\text { Skill }\end{array}$ & $\begin{array}{c}\text { Leadership } \\
\text { Skill }\end{array}$ & $\begin{array}{c}\text { Organizational } \\
\text { Performance }\end{array}$ \\
\hline Communication & 0.837 & & & & \\
\hline Creativity & 0.826 & & & & \\
\hline Teamwork & 0.783 & & & & \\
\hline Adaptability & 0.773 & & & & \\
\hline Emotional Intelligence & 0.758 & & & & \\
\hline Responsibility & 0.723 & & & & \\
\hline Critical Thinking & & 0.841 & & & \\
\hline Problem Solving & & 0.637 & & & \\
\hline Information Literacy & & & & & \\
\hline Technical Knowledge & & & 0.618 & & \\
\hline Innovative abilities & & & & & \\
\hline Motivation & & & & 0.879 & \\
\hline Conflict Management & & & & & \\
\hline Goal Clarity & & & & \\
\hline
\end{tabular}




\begin{tabular}{|c|c|c|c|c|c|}
\hline Self Efficacy & & & & & 0.577 \\
\hline Financial performance & & & & & 0.535 \\
\hline $\begin{array}{c}\text { Total Variance Explained } \\
(92.283 \%)\end{array}$ & $\mathbf{3 2 . 5 5 4}$ & $\mathbf{1 8 . 5 6 3}$ & $\mathbf{1 5 . 8 7 5}$ & $\mathbf{1 4 . 3 3 9}$ & $\mathbf{1 0 . 9 5 2}$ \\
\hline $\begin{array}{c}\text { Cronbach Alpha Reliability } \\
(\mathbf{0 . 9 7 6 )}\end{array}$ & $\mathbf{0 . 9 7 6}$ & $\mathbf{0 . 9 2 1}$ & $\mathbf{0 . 9 6 2}$ & $\mathbf{0 . 9 5 4}$ & $\mathbf{0 . 9 2 1}$ \\
\hline
\end{tabular}

The factor analysis extracted five factors to determine the employability skill at the Organizational namely interpersonal skill, functional skill, technical skill and leadership skill and Organizational performance with $92.283 \%$ variance. The overall cronbach alpha value is 0.976 which indicates excellent internal consistency level. The factor loading ranges between 0.535 to 0.894 . The extracted factors were explained in detail below.

\section{Impact of Competencies on Organizational Performance}

Impact of competencies in organizational performance was examined using regression analysis. Employability skills of the Organizational performance in IT/ITES employees considered as predictor and the Organizational performances considered as criterion variable.

$$
\begin{array}{ll}
\text { Multiple R Value : } 0.930 \\
\text { R Square Value } & : 0.866 \\
\text { F value } & : 313.818 \\
\text { P value } & :<0.01 *
\end{array}
$$

Table 4: Variables in the Regression Analysis

\begin{tabular}{|c|l|c|c|c|c|c|}
\hline \multicolumn{2}{|c|}{ Model } & \multicolumn{2}{|c|}{$\begin{array}{c}\text { Unstandardized } \\
\text { Coefficients }\end{array}$} & $\begin{array}{c}\text { Standardized } \\
\text { Coefficients }\end{array}$ & \multirow{2}{*}{ t } & \multirow{2}{*}{ Sig. } \\
\cline { 3 - 6 } & & $\mathbf{B}$ & Std. Error & Beta & & \\
\hline 1 & $($ Constant $)$ & -0.85 & 0.305 & & -2.783 & 0.006 \\
\hline & Interpersonal $\left(\mathrm{x}_{1}\right)$ & 0.136 & 0.027 & 0.253 & 4.967 & $<0.01^{*}$ \\
\hline & Functional $\left(\mathrm{x}_{2}\right)$ & 0.528 & 0.051 & 0.508 & 10.406 & $<0.01^{*}$ \\
\hline & Technical $\left(\mathrm{x}_{3}\right)$ & 0.127 & 0.055 & 0.084 & 2.317 & 0.022 \\
\hline & Leadership $\left(\mathrm{x}_{4}\right)$ & 0.3 & 0.071 & 0.18 & 4.227 & $<0.01^{*}$ \\
\hline
\end{tabular}

a. Dependent Variable: organizational Performance

It can be inferred that organizational performance as a dependent variable $-86.6 \%$ of Organizational performance was explained by employability skill with the correlation of R-0.930, F value is 313.818 and p value is $<0.001$ shows at $1 \%$ significant level. Hence, it is concluded as employability skills positively influence of the Organizational performance in IT employee. The results indicated that the success of the employee performance at Organizational is purely relies on the employability skill.

Employability skill (x) is predictor then dependent variable Organizational performance(y)

$$
y=-0.85+0.136 x_{1}+0.528 x_{2}+0.127 x_{3}+0.3 x_{4}
$$

\section{RECOMMENDATIONS}

They apparent from the findings that Human Resource performance (Compensation, Career Planning, Performance Appraisal, Training, and Employee Involvement) has a favourable position in growing the worker's overall 
performance, so the groups must implement those performances to achieve the fevered dreams. The agencies need to utilize diffusion of reward and reputation programs to drive behaviour that promotes high overall performance. The organization conducts a sizeable schooling program for Employees relevant to the changing needs of jobs and business. Job performance ought to be considered an essential aspect of determining the reimbursement of a worker's performance. Management ought to cost the contribution and thoughts shared by personnel and empower employees to maximize their skills to make effective decisions. Human Resource Management performance (Compensation, Career Planning, Performance Appraisal, Training, and Employee Involvement) plays a vital function in increasing worker performance so the groups ought to revise their HR rules using preserving in view the above elements to obtain the focused goals.

\section{CONCLUSIONS}

Employability is the enhancement of Performance and personal attributes that help in getting employed, achieving success in the chosen career and having an edge over other contenders. The Performance not only help a candidate or employees to land or sustain in a desired job, it enables one to grow as an individual to benefit the workforce and a country's economy. The primary aim of the study is to find out the importance of employability at Organizational. It is found that interpersonal skill, technical skill, functional skill and leadership skill of an employee plays a significant role in measuring the Organizational performance. The employees have to enhance their occupational skill to sustain in the job, they need to adapt themselves in every job situation as industry or employer demand. Every job demands its own skill set to perform at the Organizational. They are important to learn and acquire the required skillset at work place. The organization needs to train and facilitate the employees to update the knowledge and skills requires at the work environment. Employability Performance are not job specific, but are Performance which cut horizontally across all industries and vertically across all jobs from entry level to chief executive officer (Sherer \& Eadie 1987).

\section{REFERENCES}

1. Aycan, Z., Kanungo, R., Mendonca, M., Yu, K., Deller, J., Stahl, G., Kurshid, A. (2000). Impact of culture on human resource management performance: A 10 $\square$ country comparison. Applied Psychology, 49(1), 192-221.

2. Ahmad, S., Schroeder, R.G. (2003). The impact of HR performance on operational performance: recognizing country and industry differences. Journal of operations Management, 21(1), 19-43.

3. Arthur, J.B. (1994). Effects of human resource systems on manufacturing performance and turnover. Academy of Management journal, 37(3), 670-687.

4. Armstrong, M., (2006). A Handbook of Human Resource Management Practice (10th edition), London \& Philadelphia, Kogan Page Ltd.

5. Boselie, P., Dietz, G., Boon, C. (2005). Commonalities and contradictions in HRM and performance research. Human Resource Management Journal, 15(3), 67-94.

6. Brown, P.B. (2005). The evolving role of Strategic Management Development, Journal of Management Development, 24, 209222.

7. Karbalaei, B., \& Shirvani, N. U. K. (2015). Mediating effect of occupational health and employees well being on organizational performance. Int J Res Bus Manag (IJRBM), 3, 29-42.

8. Brown, M.P., Sturman, M.C., Simmering, M.J. (2003). Compensation policy and organizational performance: The efficiency, operational, and financial implications of pay level and pay structure. Academy of Management Journal, 46(6), 752-762. 
9. Collins, C. J., Clark, K.D. (2003). Strategic human resource performance, top management team social networks, and firm performance: The role of human resource performance in creating organizational competitive advantage. Academy of management Journal, 46(6), 740-751.

10. Hosain, M. D. (2017). The Impact of E-HRM on Organizational Performance: Evidence from Selective Service Sectors of Bangladesh.

11. Cook, C.W., Hunsaker, P.L. (2001). Management and organizational behavior. McGraw-Hill/Irwin.

12. Delery, J.E., Doty, D.H. (1996). Modes of theorizing in strategic human resource management: Tests of universalistic, contingency, and configurational performance predictions. Academy of management Journal, 39(4), 802-835. 
